\title{
<症例報告 >
}

\section{視床出血像を示した，一側内頸動脈形成不全を伴う 後交通動脈動脈瘤の 1 例}

\author{
布施 孝久 ${ }^{1 / 2)}$ 市橋 鋭一 ${ }^{2)}$ 松尾 直樹 ${ }^{2)}$ 安部 友康 ${ }^{11}$ 小山 英樹 ${ }^{1)}$
}

要旨：一側内頸動脈形成不全に伴う後交通動脈動脈瘤は非常に稀である。 今回，右内頸動 脈形成不全を有し，右後交通動脈に発生した脳動脈瘤が破綻し，脳内出血像を示した症例を 経験した．本例は右中大脳動脈が右後交通動脈を介して椎骨脳底動脈系から血流を受けてい た．MRI 所見から出血は動脈瘤壁外側に存在しており，部分血栓化動脈瘤ではないと判断さ れた，治療法は直達術ではリスクが高いと考え，瘤内塞栓術をダブルカテーテル法で施行し た，術後 2 年を経て，経過良好であるが，今後も慎重な観察が必要と考えている.

Key words : internal carotid artery aplasia, posterior communicating artery aneurysm, thalamic hemorrhage, coil embolization

(脳卒中 $31: 337-341 ， 2009$ )

\section{はじめに}

内頸動脈の形成不全は稀な先天性血管奇形であり, 血管撮影などで偶然に認められることが多い.しかし 形成不全に関連した血行動態の変化のため, 脳虚血 や痤攣, 頭蓋内出血を発症することが報告されてい る $^{1) \sim 5)}$.

今回, 我々は一側内頸動脈形成不全に併発した後交 通動脈動脈瘤が破綻し，脳内出血を示した症例を経験 した，早期の致死的再出血を予防するため，瘤内コイ ル塞栓術を施行したが，一側内頸動脈閉塞に後交通動 脈動脈瘤が併発するのは非常に稀であり，若干の文献 的考察を加えて報告する.

\section{症例}

42 歳男性.

既往歴：高血圧, 高脂血症, 痛風.

現病歴：突然の左片麻痺，左半身知覚低下，意識障 害にて救急搬入された．頭部 CT で右視床付近に出血 像を認めた(Fig. 1A)。続いて施行した脳血管撮影で は右内頸動脈欠損を認めた (Fig. 2A)。右前大脳動脈

\footnotetext{
1) 公立福生病院脳神経外科

2) 袋井市民病院脳神経外科

(2009 年 4 月 21 日受付, 2009 年 6 月 24 日受理)
}

は左前交通動脈を介して灌流され，右中大脳動脈は後 交通動脈を介し，椎骨脳底動脈領域から灌流されてい た(Fig. 2B). 右後交通動脈は拡張蛇行し, 動脈瘤が 認められた(Fig. 3A)．3D-DSA では狭窄，拡張，蛇 行を伴う後交通動脈に発生する動脈瘤が確認された (Fig. 3B). 右後大脳動脈は $\mathrm{P} 2$ 以降で描出されず，末 梢領域は中大脳動脈からの leptomeningeal anastomosis で灌流されていた，異常な血管網や内頸－外頸動脈吻 合はみられなかった。骨条件の CT では右側の動脈管 遺残がみられた(Fig. 1B)。 MRI では冠状断撮影で動 脈瘤先端部から視床に向けて血腫が存在したが，いわ ゆる瘤内部分血栓化動脈瘤ではなく，出血は動脈瘤壁 外側の脳実質内へ破綻したことによるものと判断され た (Fig. 1C). 突発性の片麻痺と意識障害という症状 からも，本例は内頸動脈欠損に伴った，後交通動脈の 動脈瘤が出血し CT 上視床出血像を呈したと推察した.

MRI 所見から出血部位は瘤先端部と考え，まず早 期の再出血を予防するために，血管内治療による動脈 瘤の塞栓術を選択した。動脈瘤は頸部が広いため、コ イルの滑落を防ぐためにも adjunctive technique が必 要と考え, ダブルカテーテルによる塞栓を行った.

カテーテルにはExcelsior1018 と Plower14を用 い，それぞれ動脈瘤内に留置し，まず Excelsior1018 から DCS $10 \mathrm{~mm} \times 30 \mathrm{~cm}$ にてフレーミングを行い, コイルをそれぞれのカテーテルから留置, 切断しなが 


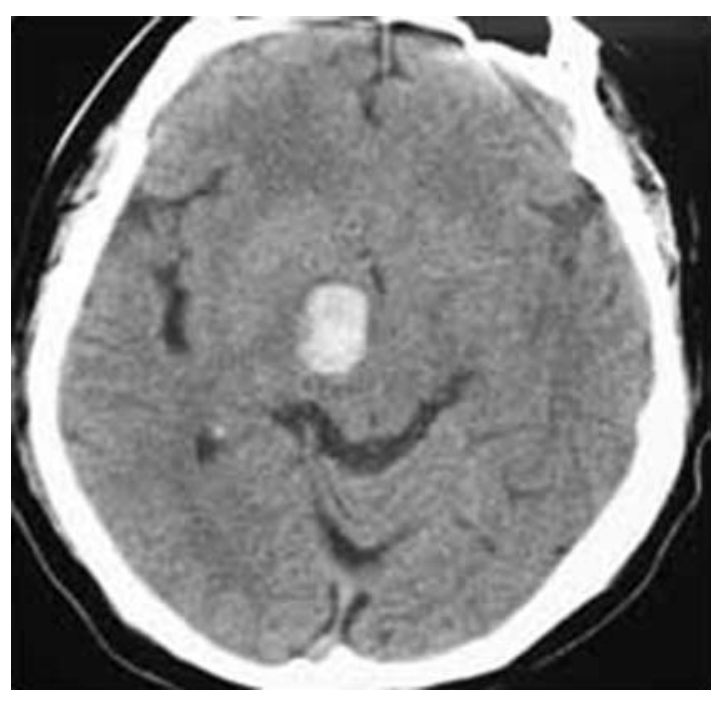

Fig. 1A 頭部 CT

右視床付近に脳内血腫を認める.

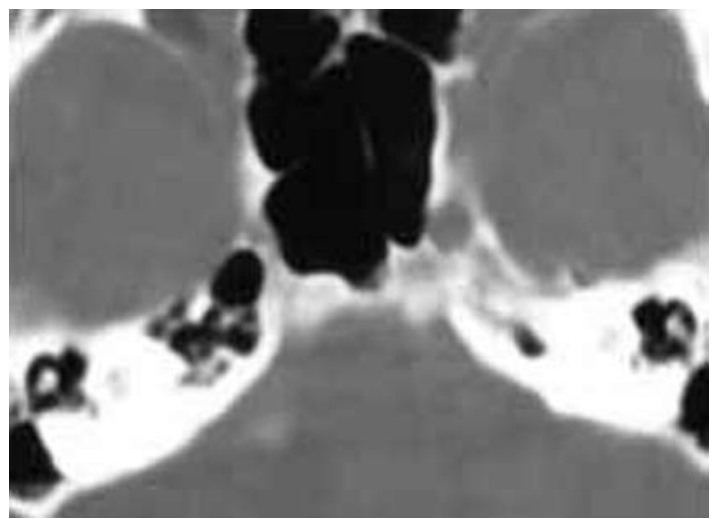

Fig. 1B 頭蓋底部 CT

右頸動脈管は狭小化しているが，遺残がみられる。

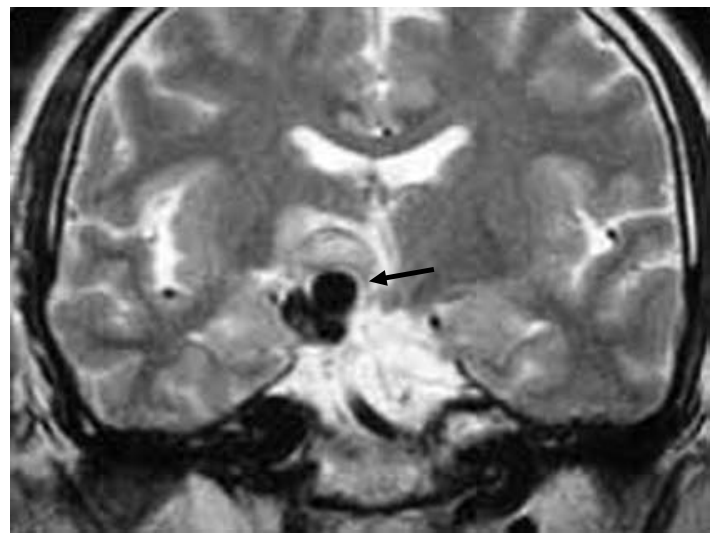

Fig. 1C 頭部 MRI

脳動脈瘤壁 (矢印)の外側に血腫が認められる。

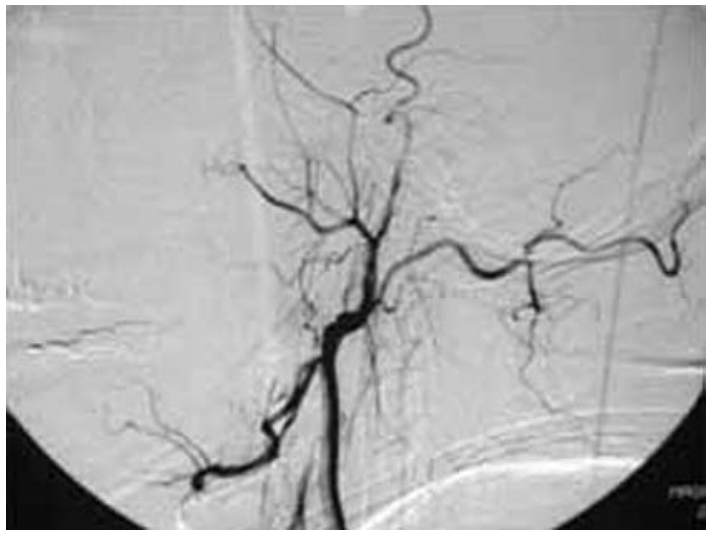

Fig. 2A 右総頸動脈撮影 右内頸動脈が描出されない.

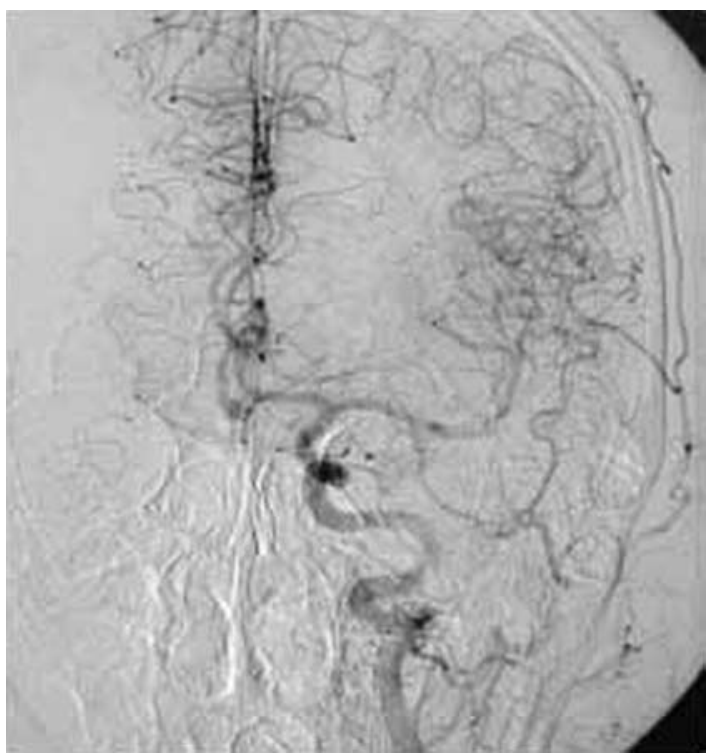

Fig. 2B 左総頸動脈撮影

左内頸動脈は両側前大脳動脈および左中大脳動脈を灌流 している.

ら交互に 5 本挿入したが，ここでカテーテルが動脈瘤 より脱落した，後交通動脈の血流を妨げない状態で動 脈瘤先端部は塞栓されたと観察されたので，塞栓術は 終了した，術後経過は良好で，リハビリテーションに て独歩可能となった。しかし経過観察目的に行った 6 カ月後の血管撮影ではコイルコンパクションが確認さ れ，再度，塞栓術を施行した(Fig. 3C)。カテーテル は Excelsior 1018 と SL-10を用いた。今回はカテーテ ルの塞栓術中の逸脱を防ぐため, Excelsior 1018 から 


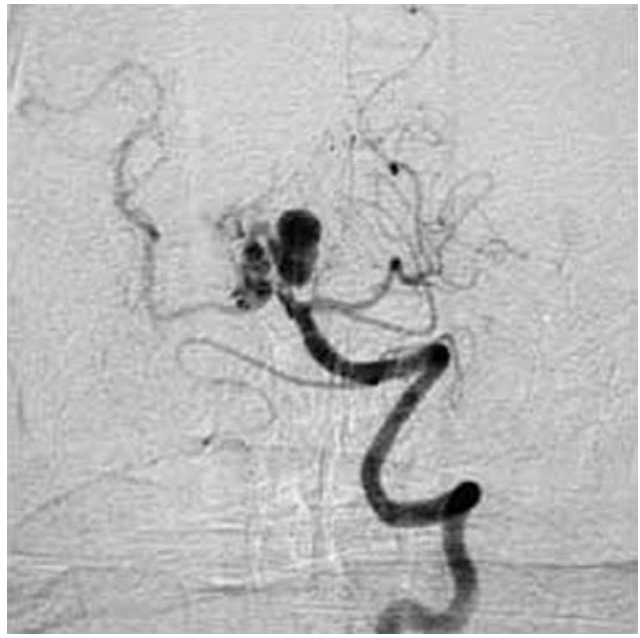

Fig. 3A 左椎骨動脈撮影

右後交通動脈を介し，右中大脳動脈が描出される。 また脳動脈瘤が右後交通動脈起始部に認められる。

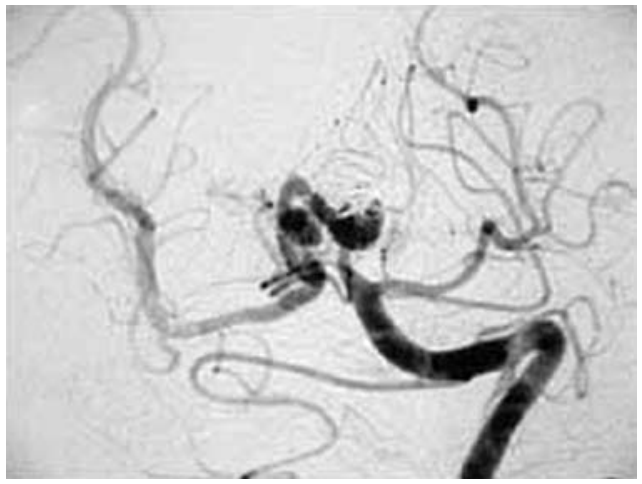

Fig. 3C 脳動脈瘤は先端部のみ部分塞栓されている

GDC 18soft を留置し，切断せずにコイルのサポート とし, SL-10 から残りのコイルを 15 本充填していっ た，十分に瘤内が埋まったところで, Excelsior 1018 の最初のコイルを離断し, SL-10で最後に挿入したコ イルを離断した．直後の血管撮影で一過性の後交通動 脈の描出の悪化が見られたが, すぐ改善し特に症状の 悪化もなく治療は終了した. 術後 9 日目の血管撮影で は, 特に血流障害は認めなかった(Fig. 3D). 現在, 外来通院にて 2 年経過しているが, 麻疩も改善し, 通 常の生活を送っている.

\section{考察}

内頸動脈の形成不全は稀な血管奇形で，その頻度は

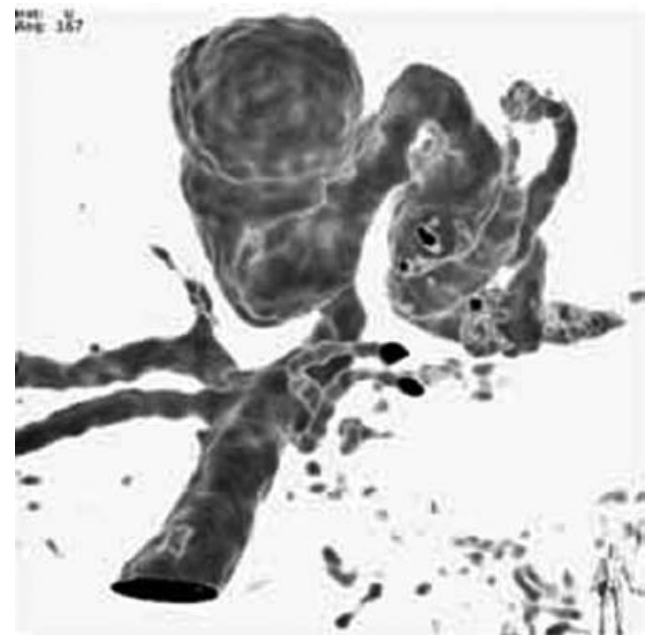

Fig. 3B 三次元脳血管撮影

右後交通動脈に動脈瘤が認められる.

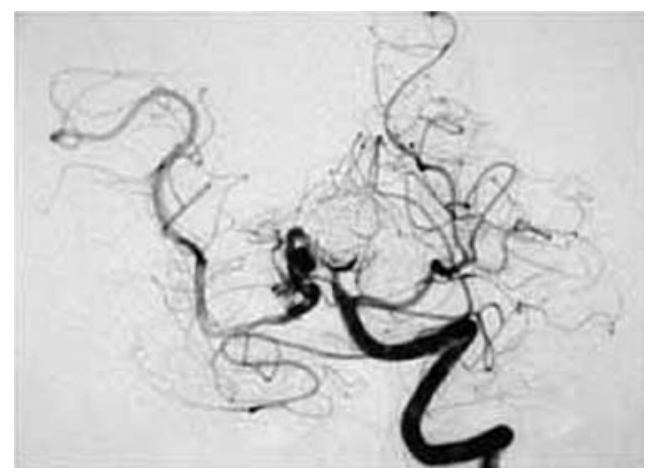

Fig. 3D 脳動脈瘤は後交通動脈に接する部分を残 して塞栓されている

剖検で $0.01 \%$ 以下と報告されている ${ }^{6)}$. 発生学的には 第一鰓弓，背側大動脈，第三鰓弓の分化，形成異常に より, 内頸動脈欠損が生じる.内頸動脈の先天的な形 成不全は agenesis と aplasia に分類され，前者は内頸 動脈の完全欠損とし頭蓋底部 CT で頸動脈管を観察す ることで判定できるという ${ }^{7)}$. 本例は CT でわずかに 動脈管遺残が認められたことから, aplasia とした. 側副血行路については fetal type と adult type に分類 されるが, adult type は前大脳動脈，中大脳動脈とも に前交通動脈を介し，血流を受ける，一方，fetal type では，前大脳動脈は前交通動脈を介し，中大脳 動脈は後交通動脈を介し，血流を受けるとされ3)，本 例もこの fetal type と考えられた. 
内頸動脈欠損を有する症例では血行動態の異常から 脳動脈瘤合併の報告が散見される ${ }^{1)}$. 特に一側内頸動 脈久損症例で合併が多く, 約 $1 / 3$ に存在したという報 告もみられる ${ }^{8)}$. 合併する動脈瘤の発生部位は多い順 から前交通動脈, 中大脳動脈, 後大脳動脈とされてい る ${ }^{2)}$. 本例の動脈瘤は後交通動脈に存在したが, 一般 にこの部位での動脈瘤発生頻度は $0.1 〜 2.8 \%$ と稀で あり ${ }^{899)}$, さらに一側内頸動脈形成不全に合併した純 粋な後交通動脈動脈瘤症例は我々が文献上涉猟したと ころでは報告がなく，非常に稀である，本症例は高血 圧, 高脂血症を有しており, 血管の動脈硬化の進行と ともに内頸動脈形成不全による hemodynamic stress が 加わり動脈瘤が発生したのではないかと推測している.

後交通動脈動脈瘤の治療法としては, 開頭クリッピ ング術を選択した報告が多い8). 後交通動脈動脈瘤の 多くは後交通動脈前半部に位置し，このため pterional approach により比較的接近しやすい症例であったと推 測される ${ }^{10)}$. しかし本例は後大脳動脈に近い部位にあ り, 頭蓋底深部となるため手術侵襲が危惧された ${ }^{788}$. また動脈瘤の trapping とバイパスの併用も考慮した が, 動脈瘤が不整形で周囲の穿通枝の状況が血管撮影 からは不明確であり，また手技も煩雑となると思われ た，一方，後交通動脈動脈瘤に対する塞栓術では穿通 枝梗塞の発生は少ないとの報告もある 栓化動脈瘤のコイル塞栓術は動脈瘤の再発, 再破裂の 可能性が高いとされるが ${ }^{11)}$, MRI 所見で血腫は動脈 瘤壁の外側に破綻しており，本例は部分血栓化動脈瘤 ではないと判断し, 瘤内塞栓術を選択した。

動脈瘤は頸部が広く、 シングルカテーテル法で詰め ることは, 後交通動脈閉塞の危険性が高く，また親血 管が狭窄，蛇行し，アシストバルーン留置も困難なた め, ダブルカテーテル法を用いた ${ }^{12)}$. 初回はコイルを 1 本ずつ切断しながら抻入したため, カテーテルが逸脱 してしまい, 部分塞栓で終了した，そこで 2 回目では 最初のフレーミングコイルを離断せず， カテーテルの アンカーとして用いることで安定したコイル塞栓の追 加が可能となった．現在術後 2 年を経て, 経過良好で
あるが，今後も慎重な経過観察を要すると考えている.

\section{参考文献}

1）姉川繁敬，鳥越隆一郎，相川洋助ら：脳動脈瘤を 伴った両側内頸動脈久損の 1 例. 脳神経 39: 517525, 1987

2）松本博之, 森脇 宏, 増尾 修ら：〈も膜下出血 で発症した中大脳動脈近位部に複雑な Anastomosis を伴う一側内頸動脈久損症の一例. 脳神経外科 28: 541-545, 2000

3）中井啓文, 川田佳克, 相沢 稀ら：前交通動脈動 脈瘤を合併した一側内頸動脈久損症の 1 例。脳神 経外科 20: 893-898, 1992

4）中村秀美, 山田洋司, 長尾朋典ら: 痓攣で発症した 内頸動脈形成不全の 1 例. 脳神経外科 21: 843-848, 1993

5）上原久生, 中野真一, 丸岡伸比古ら：脳内出血で 発症した内頸動脈久損症の 1 例. 脳神経外科 18 : 77-81, 1990

6）佐藤公俊, 山田 勝, 既内隆雄ら：脳梁出血で発 症した一側性内頸動脈形成不全症一 1 例報告と文 献的考察一. 脳神経外科 33: 613-617, 2005

7) Ide M, Jimbo M, Yamamoto M, et al: Posterior cerebral artery aneurysm associated with unilateral internal carotid artery agenesis: case report. Neurol Med Chir (Tokyo) 35: 825-829, 1995

8) Kudo T: An operative complication in a patient with a true posterior communicating artery aneurysm: case report and review of the literature. Neurosurgery 27: 650-653, 1990

9）目黒俊成，寺田欣也，廣常信之ら：肺水腫を合併 した破裂 true Pcom aneurysm に対して急性期塞 栓術を行った 1 例。脳神経外科 33: 1001-1004 2005

10）棟田耕二, 吉津法爾, 寺田洋明：True Posterior Communicating Artery Aneurysm. 脳神経外科 29: 163-168, 2001

11）加藤徳之, 江面正幸, 高橋 明ら：親動脈の近位 閉塞が奏功せず瘤内塞栓を含めた親動脈遠位閉塞 術を追加した部分血栓化巨大椎骨脳動脈瘤の 1 例。脳神経外科 28: 817-822, 2000

12) Kwon OK, Kim SH, Kwon BJ, et al: Endovascular treatment of wide-necked aneurysms by using two microcatheters: techniques and outcomes in 25 patients. AJNR 26: 894-900, 2005 


\title{
Abstract \\ Posterior communicating artery aneurysm associated with unilateral aplasia of the internal carotid artery presenting as thalamic hemorrhage: A case report
}

\author{
Takahisa Fuse, M.D. ${ }^{12)}$, Toshikazu Ichihashi, M.D. ${ }^{2)}$, Naoki Matsuo, M.D. ${ }^{2)}$, \\ Tomoyasu Abe, M.D. ${ }^{1)}$ and Hideki Koyama, M.D. ${ }^{1)}$ \\ ${ }^{1)}$ Department of Neurosurgery, Fussa Hospital \\ ${ }^{2)}$ Department of Neurosurgery, Fukuroi Municipal Hospital
}

A 42-year-old man presented with a ruptured aneurysm associated with unilateral internal carotid aplasia. He came to our hospital because of disturbed consciousness and left hemiparesis. Computed tomography showed an intraparenchymal hematoma in the right thalamic region without subarachnoid hemorrhage. Cerebral angiography demonstrated an aneurysm arising from a dilated and tortuous posterior communicating artery. The right internal carotid artery was totally absent. On coronal magnetic resonance imaging, the aneurysm was not thrombosed. Coil embolization of the aneurysm was performed by an endovascular technique using two microcatheters. In the first procedure, after achievement of coil stability with two initial coils without arterial compromise, the dome was packed mainly in the distal portion of the aneurysm to prevent rebleeding. Six months later, coil compaction was present and a re-coiling procedure was performed. In the second procedure, the dome of the aneurysm was compactly occluded. His postoperative course was uneventful. In this case, clipping or trapping of the aneurysm with an EC-IC bypass procedure was contraindicated due to the risk of causing confinement of the posterior communicating artery and perforating arteries. Therefore we chose endovascular treatment. However, continued monitoring of this patient will be necessary in the future. 